\title{
Constructing a New Optical Sensor for Monitoring Ammonia in Water Samples Using Bis(acetylacetoneethylendiamine)- tributylphosphin Cobalt(III) Tetraphenylborate Complex-Coated Triacetylcellulose
}

\author{
Ghodratollah Absalan, ${ }^{\dagger}$ Mohammad Soleimani, Mozaffar Asadi, \\ and Mohammad Bagher AHMADI
}

Department of Chemistry, Shiraz University, Shiraz 71454, Iran

\begin{abstract}
A new ammonia optical sensor was designed using bis(acetylacetoneethylendiamine)tributylphosphin cobalt(III) tetraphenylborate complex, coated on transparent triacetylcellulose film as membrane. The change in the absorbance of the optode at the maximum wavelength of $408 \mathrm{~nm}$ was related to ammonia concentration in aqueous samples. A buffer solution with a $\mathrm{pH}$ of 9 (sodium borate- $\mathrm{HCl}$ ) was used. The optode was fully regenerated in $\mathrm{pH} 2$. The linear dynamic range for determination of ammonia was $3.3 \times 10^{-4}$ to $6.9 \times 10^{-3} \mathrm{~mol} \mathrm{l}^{-1}$ with a detection limit of $5.0 \times 10^{-5} \mathrm{~mol} \mathrm{l}^{-1}$ and a response time range of $4-6 \mathrm{~min}$. This membrane was successfully applied for determination of ammonia in drinking water.
\end{abstract}

(Received March 8, 2004; Accepted May 31, 2004)

\section{Introduction}

Ammonia in water is known to be toxic to some kinds of fish,

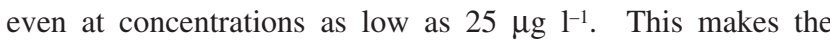
online monitoring of ammonia important for the purpose of continuously sensing ammonia in drinking water, aquariums, and bio-reactors. ${ }^{1-3}$

Colorimetric methods for ammonia determination were compared by Barnes and Sugden. ${ }^{4}$ A detection limit as low as 3 $\mu \mathrm{g}^{-1}$ has been reported. These methods can be automated by performing a continuous-flow determination. ${ }^{5-7}$ Several optical methods for the analysis of ammonia have been documented. A recommended method involves the reaction of ammonia with hypochlorite and salicylate, which in the presence of sodium nitroprusside gives a blue coloration. A similar method was recommended for seawater, with phenol and potassium ferrocyanide being used in place of salicylate and nitroprusside. ${ }^{9}$ Both methods offer high sensitivity and good precision.

Optical-sensing methods that have been used for ammonia determination are based on either the intrinsic IR-absorption of gaseous ammonia, ${ }^{10}$ or the selective reaction of a reagent with ammonia to give a detectable colorful product. ${ }^{11-13}$ Most of these methods work irreversibly and so calibrating of the respective sensor probes is difficult. Reversible sensing has been achieved by incorporating a pH-sensitive chromophore into an internal buffer placed behind, or inside, a gas permeable polymer membrane. ${ }^{14-16}$ Changes in $\mathrm{pH}$ are reversible as a result of the diffusion of ammonia into and out of the buffer. These schemes can be applied to the measurement of ammonia in aqueous solutions when the sample is iso-osmolar to the internal buffer of the sensor. If the ionic strengths inside and outside the

† To whom correspondence should be addressed.

E-mail: absalan@chem.susc.ac.ir sensor differ, the sensor drifts. This is the main limiting factor for determination of real water samples of various ionic strengths.

Such sensors respond to gases with basic properties that are capable of penetrating into the polymer. Specific carriers for ammonium (such as nonactin) were incorporated into the sensors along with an indicator dye in order to obtain more selective membranes. ${ }^{17,18}$ The resulting sensors enable highly selective determination of ammonia in gaseous and liquid samples. However, the matrices of such membranes are complex and the required materials are expensive; leaching of carrier and plasticizer has dramatic effects on both the response and stability of the sensor as well. Therefore, alternative methods should be sought.

A multitude of optodes for liquid and gaseous samples have been reported in the literature. For most of these sensors, essentially a monolayer of reagent has been immobilized by covalent bonding, ${ }^{19,21}$ by entrapment ${ }^{22-25}$ or by simple adsorption $^{26-33}$ on polymeric membranes. The optical changes are relatively weak so that sensitive detection techniques have to be employed. Fluorescent measurements are very often used. . $^{19,20,22-24,26,30-35}$ In these methods, the light is commonly brought to the membrane by an optical fiber and returned to a spectrometer for detecting. If optical absorption is employed, multipath techniques such as attenuated total reflection (ATR) implemented on specially designed waveguides or optical fibers are usually needed. ${ }^{25,36,37}$ Immobilization can also be done on small beads to obtain a large surface area to be probed by one beam. ${ }^{27,29}$ Simple one-path absorbance measurements are reported to be sufficiently sensitive in exceptional cases. ${ }^{21,38,39}$

In this research, a new optode is reported for monitoring ammonia based on bis(acetylacetoneethylendiamine) tributylphosphin cobalt(III) tetraphenylborate complex. 


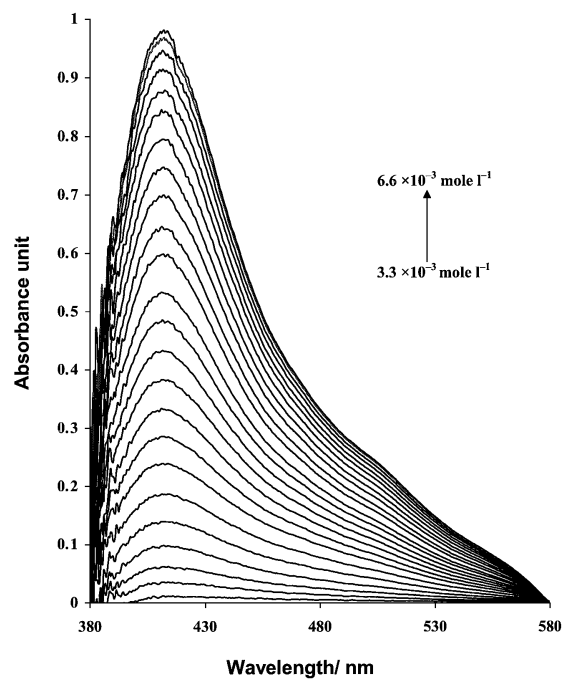

Fig. 1 Absorption spectra of complexes $\left[\mathrm{Co}(\mathrm{BAE})\left(\mathrm{PBu}_{3}\right)\right]^{+}(\mathrm{Ph})_{4} \mathrm{~B}^{-}$with different $\mathrm{NH}_{3}$ concentrations at $\mathrm{pH} 9$ $\left(3.3 \times 10^{-3}-6.6 \times 10^{-3} \mathrm{~mol} \mathrm{l}^{-1}\right)$.

\section{Experimental}

\section{Reagents}

Aqueous solutions were prepared using distilled water. Ammonium chloride, cobalt acetate $\left[\mathrm{Co}(\mathrm{OAc})_{2} \cdot 4 \mathrm{H}_{2} \mathrm{O}\right]$, tributylphosphin, ethylenediamine, and sodium tetraphenyl borate (STPB), were from Aldrich. Tetrahydrofuran (THF) and sodium borate were from Fluka and Merck, respectively. The stock solutions $(0.1 \mathrm{~F})$ of ammonia were prepared by dissolving ammonium chloride in water; hydrochloric acid was used for adjusting the $\mathrm{pH}$ to 2.0 .

\section{Synthesis of ionophore}

The ligand bis(acetylacetoneethylendiamine), BAE, was synthesized according to a procedure reported in the literature. ${ }^{40}$ Bis(acetylacetoneethylendiamine)tributylphosphin cobalt(III) tetraphenylborate, $\left[\mathrm{Co}(\mathrm{BAE})\left(\mathrm{PBu}_{3}\right)\right]^{+} \mathrm{Ph}_{4} \mathrm{~B}^{-} \cdot \mathrm{H}_{2} \mathrm{O}$, was prepared by the method described by Tauzher et al. ${ }^{40}$

To a refluxing solution of BAE $(2.01 \mathrm{mmol}, 0.45 \mathrm{~g}$ in $70 \mathrm{ml})$, $\mathrm{Co}(\mathrm{OAc})_{2} \cdot 4 \mathrm{H}_{2} \mathrm{O}(2.01 \mathrm{mmol}, 0.5 \mathrm{~g})$ and tributylphosphine $(2.01$ mmol, $0.5 \mathrm{ml}$ ) were added. The produced Co(II) complex was oxidized by blowing air for $2 \mathrm{~h}$ into the solution. The solution was filtered afterward. To the filtrate, an appropriate amount of STPB $(0.5 \mathrm{~g}$ in $10 \mathrm{ml}$ water $)$ was added. The green crystals were formed after $24 \mathrm{~h}$. The crystals were washed with methanol, recrystallized in acetone/ethanol 95\%, and dried in vacuum at $65^{\circ} \mathrm{C}$.

\section{Membrane preparation}

The transparent triacetylcelluose membranes were produced from waste photographic film tapes that had been previously treated for a few seconds with commercial sodium hypochlorite in order to remove the colored gelatinous layers. Then, the membranes were treated for 2 min with a clear solution of 10 $\mathrm{mg} \mathrm{ml}^{-1}$ of $\left[\mathrm{Co}(\mathrm{BAE})\left(\mathrm{PBu}_{3}\right)\right]^{+}(\mathrm{Ph})_{4} \mathrm{~B}^{-}$complex in THF. They were washed with water for removing THF and loosely trapped dyes, and then were washed with acetone for removing the extra dye. For improving the hydrophilicity, we placed the membranes between two filter papers moistened with diluted (1:4) hydrochloric acid solution for $120 \mathrm{~min}$ at ambient

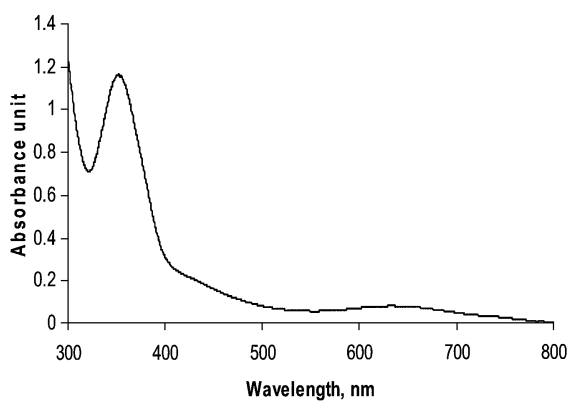

Fig. 2 Absorption spectrum of the optode in the absence of ammonia (blank spectrum) at $\mathrm{pH} 9.0$.

temperature. The membranes were washed with distilled water, and then were treated with borate buffer solution $(\mathrm{pH} 9)$ for 24 h. They were washed with distilled water afterward.

\section{Apparatus and recommended procedure}

A photodiode array Multi Spec 15001 Shimadzu with a 1-cm quartz cell was used for absorbance measurements. The constructed membrane was mounted into the spectrophotometer cell, already filled with a known volume of borate buffer $(\mathrm{pH}$ 9). Then, a sample containing ammonia was injected into the cell. The absorbance was measured over the wavelength range of $380-580 \mathrm{~nm}$ at $1 \mathrm{~nm}$ intervals or at the fixed wavelength of $408 \mathrm{~nm}$ while the constructed membrane mounted into the spectrophotometer cell, already filled with a known volume of borate buffer ( $\mathrm{pH} 9$ ), was taken as the blank. Absorbance data were transformed into ASCII files. A Metrohm $632 \mathrm{pH}$ meter with a Metrohm 6.0202.1200 glass electrode was used for monitoring the $\mathrm{pH}$ value. All measurements were performed at ambient temperature.

\section{Results and Discussion}

The constructed optical sensor works on the basis of a complex formation system. In this device, optode membranes contain cationic complexes. Sodium tetraphenylborate (STPB) was used as counter ion because it increases the lipophilicity of the membranes, when exposed to an aqueous sample containing ammonia. The latter diffuses into the membrane, then connects to the cobalt complex according to the reaction shown below:

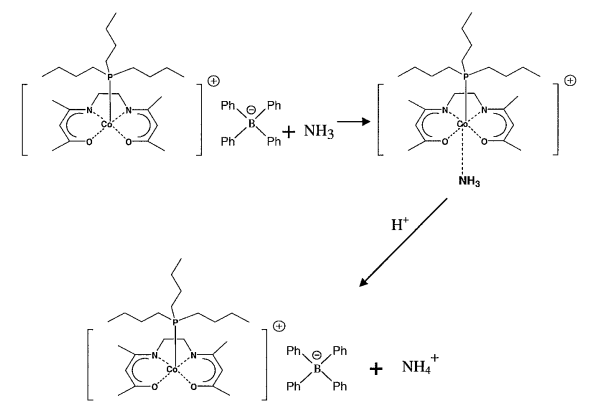

Absorption spectra of the optode, taken for different ammonia concentrations $\left(3.3 \times 10^{-4}-6.6 \times 10^{-3} \mathrm{M}\right)$ at $\mathrm{pH} 9$, are shown in Fig. 1. The membrane was taken as reference; it has an intense absorption at $350 \mathrm{~nm}$ (Fig. 2). The results show that the absorption spectra have a maximum at $408 \mathrm{~nm}$. 


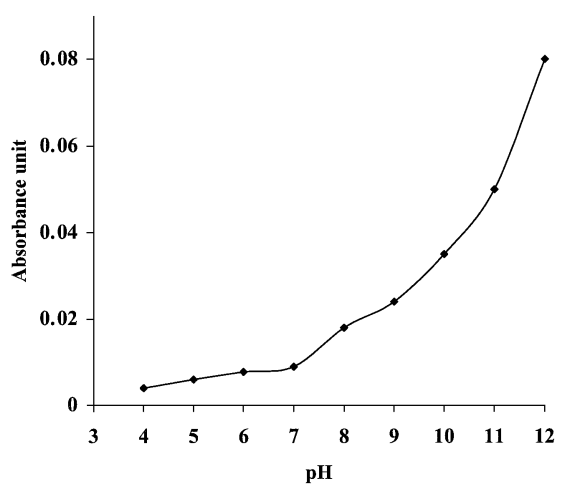

Fig. 3 The effect of $\mathrm{pH}$ on membrane (blank) response in the absence of ammonia.

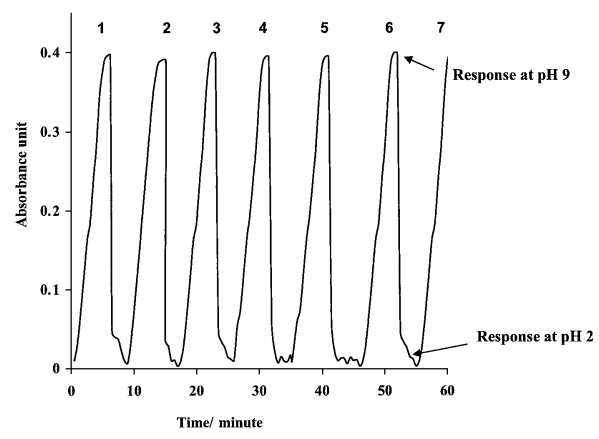

Fig. 4 Reproducibility of the membrane response at $408 \mathrm{~nm}$ in the presence of $3 \times 10^{-3} \mathrm{~mol} \mathrm{l}^{-1}$ ammonia.

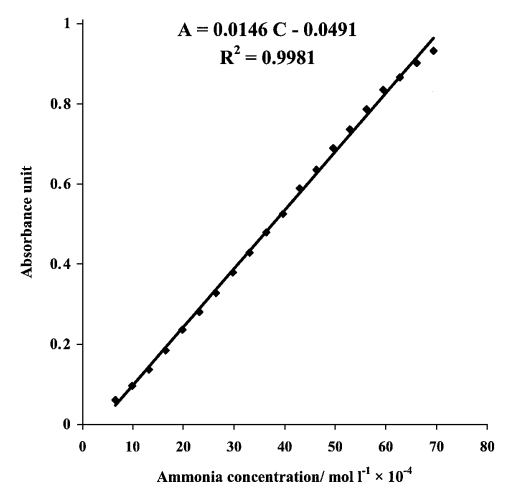

Fig. 5 Absorbance of optode as a function of ammonia concentration at $\mathrm{pH}$ 9.0. $A$, the absorbance; $C$, the concentration of ammonia.

\section{Characteristics of the sensor membrane}

Response time (defined as the time required reaching the $90 \%$ of the peak signal) was found to be $4-6$ min when the absorbance of $3 \times 10^{-3} \mathrm{M}$ ammonia was monitored as a function of time (data are not shown). Response time is affected by different factors including: ammonia concentration, diffusability of ammonia in the membrane and the dye loading technique. At very low concentrations of dye, the response time was observed to decrease.

The effect of $\mathrm{pH}$ on the membrane response (background absorbance) was studied over the $\mathrm{pH}$ range of $4-12$ in the absence of ammonia (Fig. 3) in order to obtain the optimum $\mathrm{pH}$ for monitoring the amount of $\mathrm{NH}_{3}$ in an unknown sample.
Table 1 Interference effects of selected anions and cations on determination of ammonia

\begin{tabular}{cc}
\hline Ion added & $\begin{array}{c}\text { Tolerance limit/ } \\
\mu \mathrm{g} \mathrm{m} l^{-1}\end{array}$ \\
\hline $\mathrm{SCN}^{-}, \mathrm{Cl}^{-}, \mathrm{ClO}_{4}^{-}, \mathrm{CH}_{3} \mathrm{COO}^{-}, \mathrm{NO}_{2}^{-}, \mathrm{NO}_{3}^{-}$, & $>500$ \\
tartarate, citrate & \\
$\mathrm{Cr}^{3+}, \mathrm{Co}^{2+}, \mathrm{Fe}^{3+}, \mathrm{Ag}^{+}, \mathrm{Zn}^{2+}, \mathrm{Hg}^{2+}, \mathrm{Ni}^{2+}, \mathrm{Cu}^{2+}, \mathrm{Al}^{3+}$ & $>500$ \\
$\mathrm{C}_{2} \mathrm{H}_{5} \mathrm{NH}_{2}, \mathrm{CH}_{3} \mathrm{NHCH}_{3}, \mathrm{C}_{3} \mathrm{H}_{7} \mathrm{NH}_{2}$ & $>200$ \\
$\mathrm{CH}_{3} \mathrm{NH}_{2}$ & 30 \\
\hline
\end{tabular}

Table 2 Recovery results for different concentrations of ammonia spiked in tap water of Shiraz City, Fars, Iran

\begin{tabular}{cccc}
\hline Sample & Added $/ \mathrm{mol} \mathrm{l}^{-1}$ & Found $/ \mathrm{mol} \mathrm{l}^{-1}$ & Recovery, \% \\
\hline 1 & 6 & 5.8 & 96.6 \\
2 & 15 & 14.0 & 93.3 \\
3 & 30 & 32.0 & 106.6 \\
4 & 50 & 48.5 & 97.0 \\
5 & 70 & 75.0 & 107.1 \\
\hline
\end{tabular}

With a $\mathrm{pH}$ of 7.13 , total hardness of $563 \mathrm{mg} / \mathrm{l}$, a conductivity of 1.06 $\mathrm{mS}, \mathrm{Ca}^{2+} 112.1 \mathrm{mg} / \mathrm{l}, \mathrm{Mg}^{2+} 72.7 \mathrm{mg} / \mathrm{l}, \mathrm{Cl}^{-} 114.5 \mathrm{mg} / \mathrm{l}, \mathrm{Na}^{+} 56.53 \mathrm{mg} / \mathrm{l}$, $\mathrm{K}^{+} 3.33 \mathrm{mg} / \mathrm{l}, \mathrm{SO}_{4}{ }^{2-} 189.7 \mathrm{mg} / \mathrm{l}$.

Figure 3 shows that the background absorbance is low at acidic solutions. Since ammonia is protonated at acidic $\mathrm{pH}$, it was decided to work at basic solutions to increase the sensitivity. But, at $\mathrm{pH}$ values above 9, it was observed that the membrane absorbance came close to interfering with the $\mathrm{NH}_{3}$ absorbance, which resulted in a narrow linear dynamic range. It seemed that $\mathrm{pH} 9$ could be an appropriate $\mathrm{pH}$ value for this study, so it was selected as the optimum $\mathrm{pH}$ value for the rest of the work.

The repeatability of the membrane response at $408 \mathrm{~nm}$ for alterative changes of $\mathrm{pH}$ from 2 to 9 and vice versa, when analytical concentration of ammonia was $3 \times 10^{-3} \mathrm{~mol} \mathrm{1}^{-1}$, is shown in Fig. 4. This observation showed that the optode worked in a reversible manner.

Repeated measurements showed that the changes in the absorbance, after keeping the membrane in aqueous solutions for 30 days, were less than $3 \%$. This stability of the membrane with the immobilized dye, based on the recycled support made from waste films, could be due to the higher mechanical strength of the carrier.

The absorbance of the optode as a function of ammonia concentration (Fig. 5) showed that the dynamic range was linear in the concentration range of $6.6 \times 10^{-4}-6.9 \times 10^{-3} \mathrm{M}$ of ammonia. The magnitude of the correlation coefficient was found to be 0.9981 for the fitting curve.

\section{Interference study}

The interference effects of several selected anions and cations on determination of ammonia were studied and no interference was observed (Table 1). The tolerance limit for an ion was considered as the amount of that ion which produced a signal as high as the background signal. Large amounts of phosphate were found to reduce the absorbance considerably. Among the different amines tested, the large-shaped amines did not interfere.

\section{Real sample analysis}

In order to assess the applicability of the sensor to the analysis of ammonia in real samples, recovery of spiked ammonia from 
tap water (Shiraz, Fars Province, Iran) was studied. The results along with the quality of the tap water are shown in Table 2 .

\section{Conclusions}

The results of this study indicated that ammonia concentration at levels as low as $5 \times 10^{-6} \mathrm{~mol} \mathrm{l}^{-1}$ can be measured. The advantages of the optode membrane are its safety, reproducibility and low cost. This membrane was successfully applicable for determination of ammonia in drinking water.

\section{Acknowledgements}

The authors are grateful to the Shiraz University Research Council for financial support of the project. We also appreciate Shiraz Water and Wastewater Company for providing us beneficial information about the water quality of tap water.

\section{References}

1. Y. Aoi, Y. Shiramasa, S. Tsuneda, A. Hirata, A. Kitayama, and T. Nagamune, Water Sci. Tec., 2002, 46, 439.

2. C.-H. Wu, L. Scampavia, J. Ruzicka, and B. Zamost, Analyst, 2001, 126, 291.

3. W. E. Holben, K. Noto, T. Sumino, and Y. Suwa, Appl. Environ. Microbiol., 1998, 64(7), 2528.

4. A. R. Barnes and J. K. Sugden, Pharm. Acta Helv., 1990, 65,258 .

5. M. D. L. Torre, M. D. L. Castero, and M. Valcarcel, Talanta, 1992, 39, 869.

6. T. K. V. Krawczyk and M. Trajanowicz, Anal. Sci., 1992 , 8, 329.

7. J.-Z. Zhang, P. B. Ortner, C. Fischer, and L. Moore, EPA's Manual, Suplement I, EPA/600/R-97/072, September 1997.

8. T. Werner, I. Klimant, and O. S. Wolfbesi, Analyst, 1995, $120,1627$.

9. N. Hata, K. Teraguchi, M. Yamaguchi, J. Kasahara, S. Tataguchi, and K. Goto, Microchim. Acta Helv., 1990, 65, 258.

10. S. Simhoney and A. Katzir, Appl. Phys. Lett., 1985, 47, 1241.

11. M. E. Meyerhoff and R. E. Robins, Anal. Chem., 1985, 52, 2383.

12. D. J. David, M. C. Willson, and D. S. Ruffin, Anal. Lett., 1976, 9, 389

13. Y.-S. Lee, B.-S. Joo, N.-J. Choi, J.-O. Lim, J.-S. Huh, and D.-D. Lee, Sens. Actuators B: Chemical, 2003, 93, 148.

14. O. S. Wolfbis (ed.), "Fiber Optic Chemical Sensors and Biosensors", 1991, Vols. 1 and 2, CRC Press, Boca Raton,
FL.

15. T. D. Rhines and M. A. Arnold, Anal. Chem. Acta, 1990, $231,231$.

16. G. Gauglitz and G. Kraus, Fresenius J. Anal. Chem., 1993, $349,572$.

17. S. Ozawa, P. Hauser, K. Seiler, S. S. S. Tan, W. E. Morf, and W. Simon, Anal. Chem., 1991, 63, 640.

18. S. J. West, S. Ozawa, K. Seiler, S. S. S. Tan, and W. Simon, Anal. Chem., 1992, 64, 533.

19. M. R. Fuh, L. W. Burgess, T. Hirschfeld, G. D. Christian, and F. Wang, Analyst, 1987, 112, 1159.

20. E. Urbano, H. Offenbacher, and O. S. Wolfbeis, Anal. Chem., 1984, 56, 427.

21. M. J. Goldfinch and C. R. Lowe, Anal. Biochem., 1980, 109,216

22. B. P. H. Schaffar and O. S. Wolfbeis, Anal. Chim. Acta, 1989, $217,1$.

23. B. P. H. Schaffar and O. S. Wolfbeis, and A. Leitner, Analyst, 1988, 113, 693.

24. U. J. Krull, R. S. Brown, R. F. Debono, and B. D. Hougham, Talanta, 1988, 35, 129.

25. R. R. Smardzewski, Talanta, 1988, 35, 95.

26. O. S. Wolfbis, L. J. Weis, M. J. P. Leiner, and W. E. Ziegler, Anal. Chem., 1988, 60, 2028.

27. A. J. Guthrie, R. Narayanaswamy, and N. A. Welti, Talanta, 1988, 35, 157.

28. D. C. Ashworth, H. P. Huang, R. Narayanaswamy, and R. E. Sutheriand, Anal. Chim. Acta, 1988, 213, 251

29. J. F. Alder, D. C. Ashworth, R. Narayanaswamy, R. E. Moss, and I. O. Sutheriand, Analyst, 1987, 112, 1191.

30. T. C. Warner, J. G. Cummings, and W. R. Seitz, Anal. Chem., 1989, 61, 211.

31. Y. Kawabata, R. Tahara, T. Imasaka, and N. Ishibashi, Anal. Chim. Acta, 1988, 212, 267.

32. F. V. Bright, G. E. Poirier, and G. M. Hieftje, Talanta, 1988, 35, 113.

33. P. Y. F. Li and R. Narayanaswamy, Analyst, 1989, 114, 1191.

34. K. Suzuki, K. Tohda, Y. Tanda, H. Ohzora, S. Nishihama, H. Inoue, and T. Shirai, Anal. Chem., 1989, 61, 382.

35. M. K. Carroll, F. V. Bright, and G. M. Hieftje, Anal. Chem., 1989, 61, 1768.

36. W. P. Carey, M. D. Degrandpre, and B. S. Jorgensen, Anal. Chem., 1989, 61, 1647.

37. R. L. Cook, R. C. Macduff, and A. F. Sammells, Anal. Chim. Acta, 1989, 226, 153.

38. F. L. Dikert, S. K. Schreiner, G. R. Mages, and H. Kimmel, Anal. Chem., 1989, 61, 2306.

39. H. E. Posch, O. S. Wolfbeis, and J. Pusterhofer, Talanta, 1988, 35, 89.

40. G. Tauzher, G. Mestroni, A. Puxeddu, R. Costanzo, and G. Costa, J. Chem. Soc., A, 1971, 2504. 